УДК 636.22/28.033.083.314, DOI 10.31210/visnyk2018.02.14

(C) 2018

Колісник О. І., кандидат сільськогосподарських наук, директор ПП «Агро - Новоселівка 2009» Харківської області

\author{
Прудніков В. Г., доктор сільськогосподарських наук, професор, \\ Криворучко Ю. І., кандидат сільськогосподарських наук \\ Харківська державна зооветеринарна академія
}

Нагорний С. А., кандидат сільськогосподарських наук

Харківський національний технічний університет сільського господарства ім. Петра Василенка

\title{
ПОРІВНЯЛЬНА ХАРАКТЕРИСТИКА ЕФЕКТИВНОСТІ РІЗНИХ СПОСОБІВ ВИПАСАННЯ М'ЯСНИХ КОРІВ ІЗ ТЕЛЯТАМИ НА ПІДСИСІ АБЕРДИН-АНГУСЬКОЇ ПОРОДИ
}

\section{Рецензент - доктор сільськогосподарських наук, професор С. І. Чигринов}

Розглянуто питання щчодо проведення порівняльної характеристики різних способів випасання м'ясних корів з телятами на підсисі абердин-ангуської породи на природних пасовищах Лісостепу Украӥни та розраховано технологічні карти з послідовними процесами з урахуванням пооперачійних витрат праці за добу й увесь пасовищний період. Встановлена доиільність більи ширшого застосування електропастухів під час випасання м'ясної худоби за рахунок економії людської прачі, меншої кількості працюючих та більш ефективного використання пасовищ.

Ключові слова: м'ясне скотарство, пасовища, технологія, способи випасання, технологічні карти, корови абердин-ангуської породи.

Постановка проблеми. Зміна напрямів агропромислового комплексу України змушує фахівців переглянути об'єктивні технологічні рішення та запровадити у виробництво перспективні та найбільш ефективні технології виробництва яловичини. Втім необхідно не тільки брати до уваги закордонний досвід, а й використовувати та удосконалювати власні перспективні технології, адаптовані до різних природно-кліматичних зон країни.

Одним із головних чинників, який впливає на рентабельність виробництва яловичини, $є$ ефективне використання кормових ресурсів у поєднанні з біологічними особливостями м'ясної худоби. Собівартість кормів складає 60-70 \% загальних витрат, тому особливу увагу звертають на здешевлення їх за рахунок раціонального використання. Виходячи 3 цього, максимальне використання пасовищ м'ясною худобою у випадку застосування нагулу $є$ незаперечним ефективним елементом технології м'ясного скотарства. М'ясна худоба спроможна використовувати пасовища 3 ранньої весни та до пізньої осені. За пасовищний період худоба споживає до 42 ц корм. од. Це становить близько $63 \%$ річної потреби в кормах за поживністю [3].

Аналіз основних досліджень і публікацій, у яких започатковано розв'язання проблеми. Славов В. П., Доротюк Е. М., Угнівенко А. М. та інші вчені $[2,4,5]$ констатують, що випасання худоби - це $є$ найважливіший засобом рентабельного виробництва яловичини в умовах м'ясного скотарства, який заощаджує значну кількість концентрованих кормів, трудових ресурсів, паливно-мастильних матеріалів та дає можливість отримати високоякісну дешеву яловичину. Пасовищне утримання тварин практично повністю виключає витрати на скошування зеленої маси та іiї транспортування та роздавання. За загальними витратами на паливномастильні матеріали, корми, працю, підстилку, електроенергію, основні засоби, водопостачання та ін. для отримання 1 кг приросту живої маси пасовищна система ефективніша в 3-3,5 рази, порівнюючи з безпасовищною, яка застосовується в більшості господарств України.

Завдання дослідження - у випадку застосування ресурсозаощадної технології м'ясного скотарства встановити найбільш ефективний, маловитратний спосіб випасання худоби з ефективним використанням пасовищ в умовах Східного регіону України.

Матеріали та методика досліджень. Дослідження та подальші розрахунки технологічних карт у випадку різних способів випасання м'ясних корів із телятами на підсисі абердинангуської породи проводили в ПП «Агро - Новоселівка 2009» Нововодолазького району Харківської області.

Результати дослідження. Необхідно зважити на те, що запорукою ефективної технології пасовищного утримання худоби $є$ низка заходів, яких 


\section{СІЛЬСЬКЕ ГОСПОДАРСТВО. ТВАРИННИЦТВО}

необхідно чітко дотримуватись: підтримку продуктивного стану пасовищ, організації облаштування та розміщення допоміжних засобів та обладнання в загонах, чітку систему використання та догляду за пасовищами (вирубування чагарників та знищення бур'яну, прибирання каміння і сміття, періодично вносити добрива, підкошувати траву, яка була не з'їдена худобою, рівномірне розрівнювання гною, підсів тощо).

Поряд 3 цим, застосування нагулу (загіннопорційної системи випасання тварин) є основою раціонального використання пасовищ. При цьому пасовища розбивають на загони за допомогою електропастухів (електроогорожі). У порівнянні з безсистемним випасанням, це дає змогу підвищити продуктивність пасовищ до $35 \%$, раціональне використання площі пасовищ на 25$30 \%$ [1-5].

У залежності від природно-кліматичних умов й продуктивності травостою пасовищний період у господарстві триває в середньому 150-155 діб (травень - жовтень). Втім ефективність цього періоду залежить від низки заходів і прийомів щодо належного раціонального використання пасовищ у випадку зменшення трудомістких робіт технологічних процесів під час організації випасання худоби.

Одним із головних факторів зниження витрат праці в пасовищний період є застосування різних способів випасання м'ясної худоби (пішки, з використанням коня, із застосуванням електропастуха) (табл. 1-3).

\section{1. Технологічна карта утримання корів з телятами в пасовищний період у разі випасання пішки}

\begin{tabular}{|c|c|c|c|c|c|c|c|c|c|c|c|c|c|c|c|c|}
\hline \multirow[b]{2}{*}{$\begin{array}{c}\text { № } \\
\text { 3/ח }\end{array}$} & \multirow[b]{2}{*}{$\begin{array}{c}\text { Найменування } \\
\text { процесів і } \\
\text { операцій }\end{array}$} & \multirow{2}{*}{ 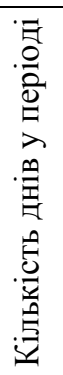 } & \multicolumn{3}{|c|}{ Об’єм роботи } & \multicolumn{5}{|c|}{ Машини і обладнання } & \multicolumn{3}{|c|}{ Витрати праці } & \multicolumn{3}{|c|}{ Виконавці } \\
\hline & & & 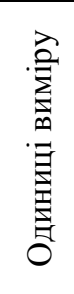 & $\begin{array}{l}\overrightarrow{0} \\
0 \\
\stackrel{1}{1} \\
\text { m }\end{array}$ & . & 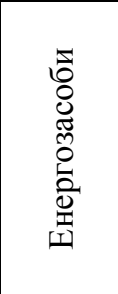 & 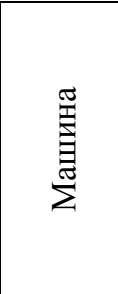 & 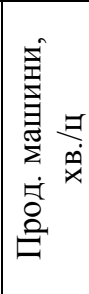 & 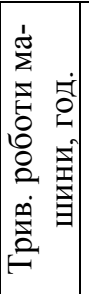 & 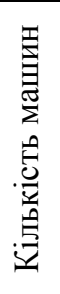 & 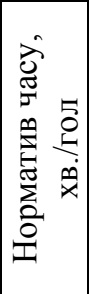 & 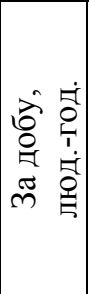 & 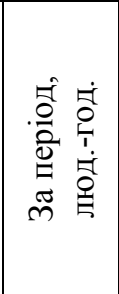 & 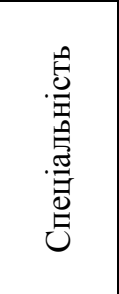 & 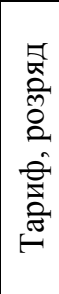 & 苞 \\
\hline 1 & $\begin{array}{l}\text { Перевезення } \\
\text { тварин }\end{array}$ & 1 & гол. & 410 & - & - & - & - & - & - & 2,07 & 14,1 & 14,1 & $\begin{array}{c}\text { Oпера- } \\
\text { тор }\end{array}$ & IV & 2,0 \\
\hline 2 & \begin{tabular}{|l|} 
Приймання та \\
передача змі- \\
ни, випасання \\
худоби та під- \\
годовування, \\
напування тва- \\
рин із корит, \\
нічне чергу- \\
вання, участь у \\
зооветзаходах, \\
інші разові \\
роботи
\end{tabular} & 150 & гол. & 220 & - & - & - & - & - & - & 11,5 & 42,3 & 6345 & $\begin{array}{l}\text { Опера- } \\
\text { тор }\end{array}$ & IV & 6,0 \\
\hline 3 & \multicolumn{16}{|c|}{$\begin{array}{l}\text { Навантаження, транспортування, роздавання } \\
\text { кормів: }\end{array}$} \\
\hline & - концкормів & 150 & $\mathrm{~T}$ & 0,88 & 132,2 & $\begin{array}{l}\text { ЮM3- } \\
6\end{array}$ & $\begin{array}{c}\Pi \mathrm{-}- \\
0,5\end{array}$ & 2,18 & 0,32 & - & 0,14 & 0,9 & 144 & Тр-т & V & 0,14 \\
\hline & - сіна & 150 & $\mathrm{~T}$ & 2,62 & 393,3 & $\begin{array}{c}\text { ЮM3- } \\
6\end{array}$ & $\begin{array}{c}\text { KTУ- } \\
10\end{array}$ & 3,16 & 1,38 & - & 0,03 & 0,2 & 30 & Тр-т & $\mathrm{V}$ & 0,03 \\
\hline & - соломи & 150 & $\mathrm{~T}$ & 0,05 & 7,4 & $\begin{array}{c}\text { ЮM3- } \\
6 \\
\end{array}$ & $\begin{array}{c}\text { KTY- } \\
10\end{array}$ & 3,16 & 0,02 & - & 0,08 & 0,5 & 81 & Тр-т & V & 0,08 \\
\hline & - силосу & 150 & $\mathrm{~T}$ & 5,5 & 826,8 & $\begin{array}{c}\text { ЮM3- } \\
6\end{array}$ & $\begin{array}{c}\text { KTY- } \\
10\end{array}$ & 1,56 & 1,43 & - & 0,46 & 3,1 & 465 & Тр-т & V & 0,4 \\
\hline & - води & 150 & $\mathrm{~T}$ & 15 & 2250 & $\begin{array}{c}\text { ЮM3- } \\
6\end{array}$ & $\begin{array}{c}\text { См- } \\
\text { ність- } \\
15 \mathrm{~m}^{3}\end{array}$ & 1,5 & 3,75 & - & 0,35 & 2,4 & 360 & Тр-т & V & 0,34 \\
\hline 4 & $\begin{array}{l}\text { Усього за } \\
\text { період }\end{array}$ & - & - & - & - & - & - & - & _- & - & - & - & 7439,1 & - & - & 9,0 \\
\hline
\end{tabular}


СІЛЬСЬКЕ ГОСПОДАРСТВО. ТВАРИННИЦТВО

\section{2. Технологічна карта утримання корів із телятами в пасовищний період у разі випасання з використанням коня}

\begin{tabular}{|c|c|c|c|c|c|c|c|c|c|c|c|c|c|c|c|c|}
\hline \multirow[b]{2}{*}{$\begin{array}{l}\text { № } \\
\text { 3/ח }\end{array}$} & \multirow[b]{2}{*}{$\begin{array}{c}\text { Найменування } \\
\text { процесів і } \\
\text { операцій }\end{array}$} & \multirow{2}{*}{ 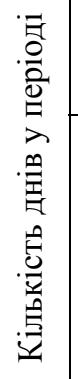 } & \multicolumn{3}{|c|}{ Об’єм роботи } & \multicolumn{5}{|c|}{ Машини і обладнання } & \multicolumn{3}{|c|}{ Витрати праці } & \multicolumn{3}{|c|}{ Виконавці } \\
\hline & & & 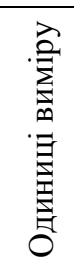 & $\begin{array}{l}\vec{b} \\
0 \\
\stackrel{1}{1} \\
\text { लू }\end{array}$ & 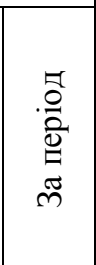 & 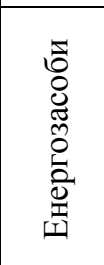 & 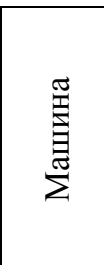 & 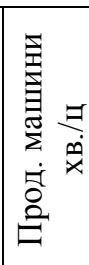 & 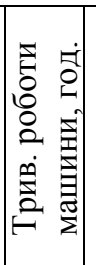 & 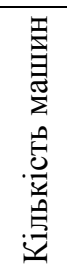 & 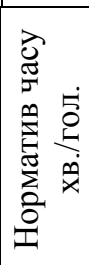 & 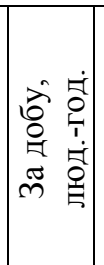 & 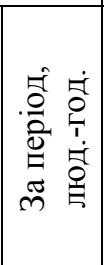 & 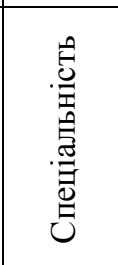 & 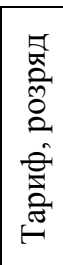 & 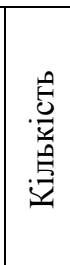 \\
\hline 1 & $\begin{array}{c}\text { Перевезення } \\
\text { тварин }\end{array}$ & 1 & гол. & 410 & - & - & - & - & - & - & 2,07 & 14,1 & 14,1 & $\begin{array}{c}\text { Oпера- } \\
\text { тор }\end{array}$ & IV & 2,0 \\
\hline 2 & \begin{tabular}{|l|} 
Приймання та \\
передача зміни, \\
випасання ху- \\
доби та підго- \\
довування, \\
напування тва- \\
рин із корит, \\
нічне чергу- \\
вання, участь у \\
зооветзаходах, \\
інші разові \\
роботи \\
\end{tabular} & 150 & гол. & 220 & - & - & - & - & - & - & 8,75 & 32,0 & 4800 & $\begin{array}{c}\text { Опера- } \\
\text { тор }\end{array}$ & IV & 4,5 \\
\hline \multirow[t]{6}{*}{3} & $\begin{array}{l}\text { Навантаження, } \\
\text { кормів: }\end{array}$ & транс & порт. & $\mathrm{HE}$ & po3t & вання & & & & & & & & & & \\
\hline & - концкормів & 150 & $\mathrm{~T}$ & 0,88 & 132,2 & $\begin{array}{c}\text { OM3- } \\
6\end{array}$ & $\begin{array}{c}\Pi У- \\
0,5\end{array}$ & 2,18 & 0,32 & - & 0,14 & 0,9 & 144 & Тр-т & V & 0,14 \\
\hline & - сіна & 150 & $\mathrm{~T}$ & 2,62 & 393,3 & $\begin{array}{c}\text { OM3- } \\
6\end{array}$ & $\begin{array}{c}\text { KTУ- } \\
10\end{array}$ & 3,16 & 1,38 & - & 0,03 & 0,2 & 30 & Тр-т & V & 0,03 \\
\hline & - соломи & 150 & $\mathrm{~T}$ & 0,05 & 7,4 & $\begin{array}{c}\text { ЮM3- } \\
6\end{array}$ & $\begin{array}{c}\text { KTY- } \\
10\end{array}$ & 3,16 & 0,02 & - & 0,08 & 0,5 & 81 & Тр-т & V & 0,08 \\
\hline & - силосу & 150 & $\mathrm{~T}$ & 5,5 & 826,8 & $\begin{array}{c}\text { OM3- } \\
6\end{array}$ & $\begin{array}{c}\text { KTY- } \\
10\end{array}$ & 1,56 & 1,43 & - & 0,46 & 3,1 & 465 & Тр-т & $\mathrm{V}$ & 0,44 \\
\hline & - води & 150 & $\mathrm{~T}$ & 15 & 2250 & $\begin{array}{c}\text { ЮM3- } \\
6\end{array}$ & \begin{tabular}{|c|} 
EM- \\
Hicть- \\
$15 \mathrm{~m}^{3}$ \\
\end{tabular} & 1,5 & 3,75 & - & 0,35 & 2,4 & 360 & Тр-т & V & 0,34 \\
\hline 4 & $\begin{array}{l}\text { Усього за } \\
\text { період }\end{array}$ & - & - & - & - & - & - & - & - & - & - & - & 5894,1 & - & - & 7,53 \\
\hline
\end{tabular}

У господарстві налічується 300 га природних пасовищ, які розміщені на відстані 3-5 км від ферми та шлях до них обмежений господарськими посівами. Тому худобу на пасовища перевозять машиною та витрати праці при цьому становлять 14,1 люд.-год. Різниці за цим показником у випадку різних способів випасання м'ясних корів із телятами на підсисі не встановлено.

Загальні витрати праці в наступних організаційно-технологічних операціях пасовищного періоду, таких як навантаження, транспортування, роздавання кормів для підгодівлі телят і корів, а також підвіз води були на рівні 1080 люд.-год./за період.

Виходячи $з$ даних рис. 1, на витрати праці сут- тєво вплинув спосіб випасання м'ясної худоби, а саме у разі використання електропастуха, коня, або пішки. Загальні операції, до яких входять такі технологічні процеси як випасання худоби, перегін тварин, приймання та передача зміни, підгодовування худоби, іï напування 3 корит, нічне чергування, участь у зооветзаходах, інші разові роботи (чергування, санітарне прибирання, прибирання гною, дрібний ремонт інвентаря, роздавання мінеральної підкормки) мають суттєву різницю в нормативах часу та витратах праці. Так, нормативи витрат часу 3 використанням електропастуха становлять 0,54 хв./гол. у разі його установки та 1,28 хв./гол. на загальні операції, у випадку використання коня і випасання пішки $-8,75$ та 11,5 хв./гол. відповідно. 


\section{3.Технологічна карта утримання корів із телятами в пасовищний період у разі використання електропастуха}

\begin{tabular}{|c|c|c|c|c|c|c|c|c|c|c|c|c|c|c|c|c|}
\hline \multirow[b]{2}{*}{$\begin{array}{l}\text { № } \\
\text { 3/ח }\end{array}$} & \multirow[b]{2}{*}{$\begin{array}{c}\text { Найменуван- } \\
\text { ня процесів і } \\
\text { операцій }\end{array}$} & \multirow{2}{*}{ 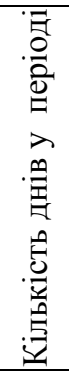 } & \multicolumn{3}{|c|}{ Об’єм роботи } & \multicolumn{5}{|c|}{ Машини і обладнання } & \multicolumn{3}{|c|}{ Витрати праці } & \multicolumn{3}{|c|}{ Виконавці } \\
\hline & & & 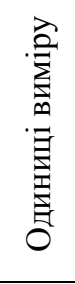 & $\begin{array}{l}\vec{b} \\
0 \\
0 \\
\tilde{\Xi} \\
\tilde{m}\end{array}$ & 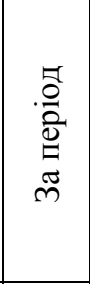 & 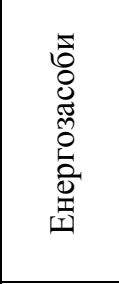 & 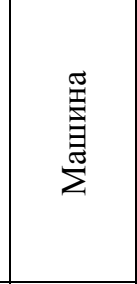 & 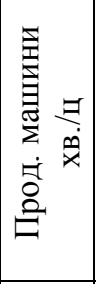 & 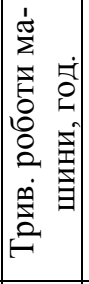 & 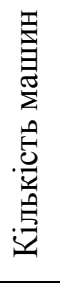 & 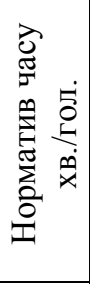 & 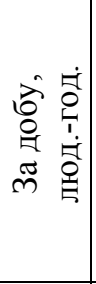 & 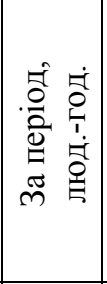 & 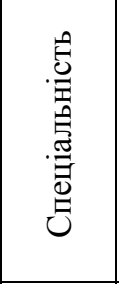 & 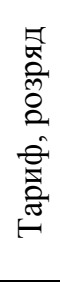 & 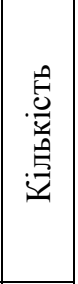 \\
\hline 1 & $\begin{array}{c}\text { Перевезення } \\
\text { тварин } \\
\end{array}$ & 1 & гол. & 410 & - & - & - & - & - & - & 2,07 & 14,1 & 14,1 & $\begin{array}{c}\text { Опе- } \\
\text { ратор }\end{array}$ & IV & 2,0 \\
\hline 2 & $\begin{array}{l}\text { Приймання та } \\
\text { передача змі- } \\
\text { ни, підгодо- } \\
\text { вування худо- } \\
\text { би, напування } \\
\text { тварин із ко- } \\
\text { рит із перегі- } \\
\text { ном тварин, } \\
\text { нічне чергу- } \\
\text { вання, участь } \\
\text { у зооветзахо- } \\
\text { дах, інші ра- } \\
\text { зові роботи* }\end{array}$ & 150 & гол. & 220 & - & - & - & - & - & - & 1,28 & 4,7 & 705 & $\begin{array}{c}\text { Опе- } \\
\text { ратор }\end{array}$ & IV & 0,67 \\
\hline 3 & $\begin{array}{l}\text { Установка } \\
\text { електропасту- } \\
\text { ха** }\end{array}$ & 10 & га & 0,33 & 50 & $\begin{array}{c}\text { Елек- } \\
\text { тропас- } \\
\text { тух } \\
\end{array}$ & Вручну & - & - & - & 0,54 & 1,98 & 198 & $\begin{array}{c}\text { Опера- } \\
\text { тор }\end{array}$ & IV & 0,28 \\
\hline \multirow{6}{*}{4} & \multicolumn{6}{|c|}{$\begin{array}{l}\text { Навантаження, транспортування, } \\
\text { роздавання кормів: }\end{array}$} & & & & & & & & & & \\
\hline & концкормів & 150 & $\mathrm{~T}$ & 0,88 & $\begin{array}{c}132 \\
2 \\
\end{array}$ & $\begin{array}{c}\text { ЮM3- } \\
6\end{array}$ & ПУ $-0,5$ & 2,18 & 0,32 & - & 0,14 & 0,9 & 144 & Tp-т & $\mathrm{V}$ & 0,14 \\
\hline & - сіна & 150 & $\mathrm{~T}$ & 2,62 & \begin{tabular}{|c|}
393 \\
3 \\
\end{tabular} & $\begin{array}{c}\text { ЮM3- } \\
6 \\
\end{array}$ & КТУ-10 & 3,16 & 1,38 & - & 0,03 & 0,2 & 30 & Тр-т & $\mathrm{V}$ & 0,03 \\
\hline & - соломи & 150 & $\mathrm{~T}$ & 0,05 & 7,4 & $\begin{array}{c}\text { ЮM3- } \\
6\end{array}$ & КТУ-10 & 3,16 & 0,02 & - & 0,08 & 0,5 & 81 & Тр-т & V & 0,08 \\
\hline & - силосу & 150 & $\mathrm{~T}$ & 5,5 & \begin{tabular}{|c|}
826 \\
8 \\
\end{tabular} & $\begin{array}{c}\text { ЮM3- } \\
6 \\
\end{array}$ & КТУ-10 & 1,56 & 1,43 & - & 0,46 & 3,1 & 465 & Tp-T & V & 0,44 \\
\hline & - води & 150 & $\mathrm{~T}$ & 15 & 2250 & $\begin{array}{c}\text { ЮM3- } \\
6\end{array}$ & \begin{tabular}{|c|}
$\epsilon_{M-}$ \\
ність - \\
$15 \mathrm{M}^{3}$ \\
\end{tabular} & 1,5 & 3,75 & - & 0,35 & 2,4 & 360 & Tp-т & $\mathrm{V}$ & 0,34 \\
\hline 5 & $\begin{array}{l}\text { Усього за пе- } \\
\text { ріод }\end{array}$ & - & - & - & - & - & - & - & - & - & - & - & 1997,1 & - & - & 3,98 \\
\hline
\end{tabular}

*Інші роботи включають: чергування, санітарне прибирання, участь у періодичному видаленні гною, дрібний ремонт інвентарю, роздавання мінеральної підгодівлі.

**Норматив установки електропастуха $=60$ хв./220 гол. $=0,27 \times 2$ чол. $=0,54$.

Найбільший відсоток витрат людино-годин припадає саме на загальні операції: в разі випасання пішки $-85,3 \%$, під час випасання на коні - $81,4 \%$ та 3 використанням електропастуха $45,3 \%$, в тому числі на установку електроогорожі - $10 \%$. Тобто перевага в економному використанні людської праці була на боці останнього способу випасання худоби.

Для забезпечення виконання всіх необхідних технологічних процесів і операцій під час утримання абердин-ангуських корів із телятами на підсисі (220 гол.) у пасовищний період на природних пасовищах в умовах Лісостепу України необхідна наступна кількість робітників:

- у разі випасання пішки - 9 чол. (2 - для перевезення, 6 - для виконання загальних технологічних операцій та 1 - для навантаження, транспортування, роздавання кормів та води), 


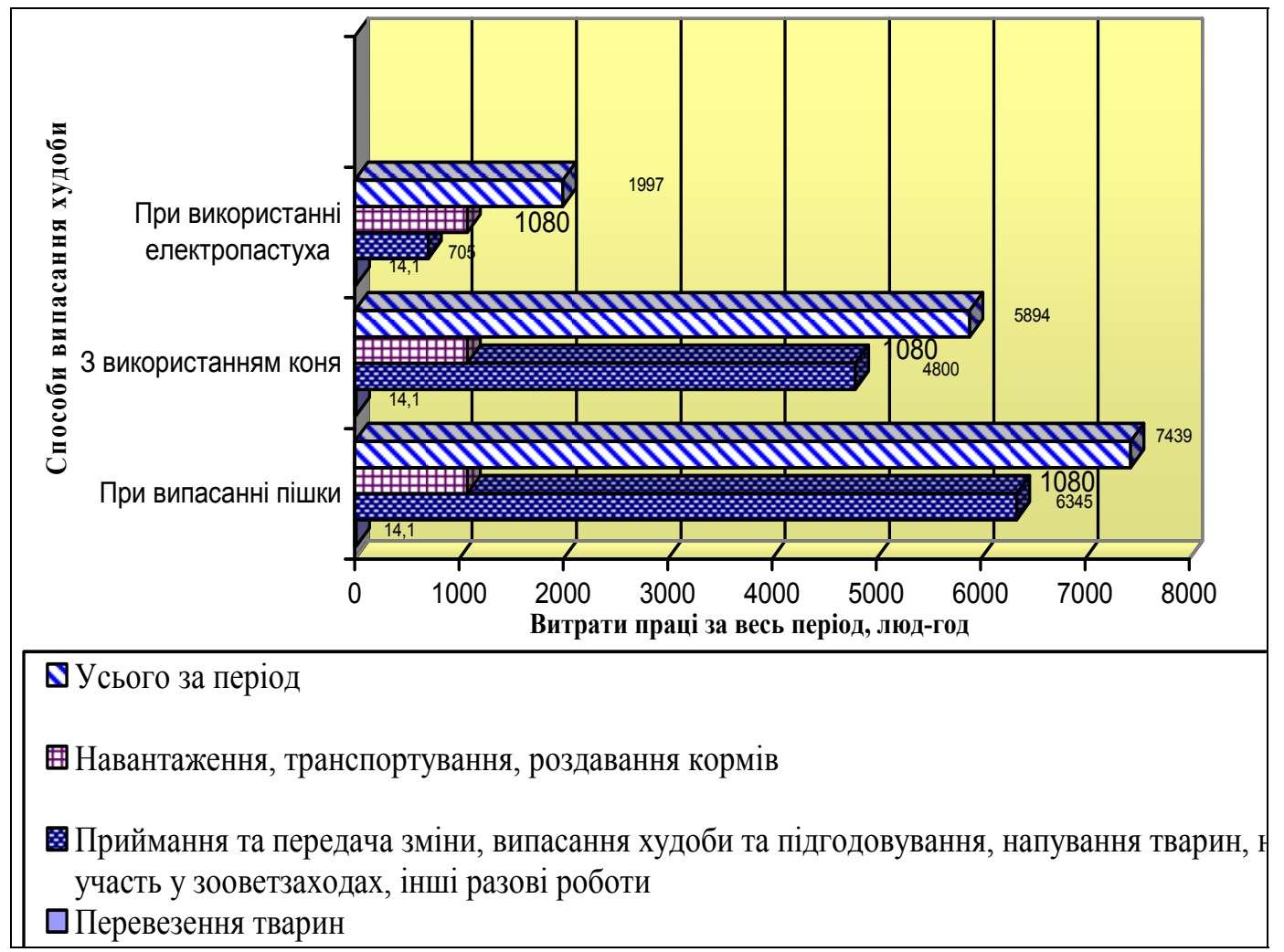

Рис. 1. Витрати праці люд.-год. за пасовищний період у випадку різних способів випасання м'ясних корів зі илейфом, \%

- у разі випасання на коні - 7,5 чол. (відповідно $2-4,5-1)$,

- за використання електропастуха - 4 чол. (2 $1-1)$.

Висновок. Під час проведення порівняльної характеристики різних способів випасання м'ясних корів абердин-ангуської породи з телятами на підсисі на природних пасовищах Лісостепу України та розрахунків технологічних карт 3 послідовними технологічними процесами була

\section{БІБЛІОГРАФІЯ}

1. Буркат В. П. Концептуальні підходи до формування галузі м'ясного скотарства // Тваринництво України. - 1997, №4. - С. 9-11.

2. Доротюк E. М. М'ясне скотарство - джерело високоякісної яловичини та шкіряної сировини. - Харків : Тираж 51, 2006. - 320 с.

3. Стратегія розвитку м'ясного скотарства в Україні у контексті національної продовольчої безпеки / М. В. Зубець, В. П. Буркат, І. В. Гузєв, встановлена перевага випасання м'ясної худоби у випадку застосування електропастухів в економії людської праці, більш ефективному використанні пасовищ та зменшенні кількості працюючих. Це дає змогу отримати дешеву яловичину не лише за рахунок пасовищ, а і за рахунок зменшення загальних витрат праці на виконання всіх необхідних технологічних процесів і операцій в пасовищний період.

Г.О. Богданов. - К.:Аграрна наука, 2005. - 176 с.

4. Славов В., Шуст П., Салоїд М. Відродити нагул великої рогатої худоби // Тваринництво України. - 2002, №6. - С. 7-11.

5. Наукові основи розвитку м'ясного скотарства в Україні / А. М. Угнівенко, С. М. Петренко, Д. К. Носевич, Ю. І. Токар : монографія. - К. : Компринт, 2016. - С. 234-252. 


\section{ANNOTATION}

Kolisnyk A. I., Prudnikov V. G., Kryvoruchko Yu. I., Nagornyi S. A. Comparative characteristics of the efficiency of different methods of determining meat coils with numbers on the surface of the Aberdeen-Angus breed.

Breeding cattle is the most important means of making beef production in the conditions of meat cattle breeding, which saves a significant amount of concentrated feed, labor resources, fuel and lubricants, and gives the opportunity to get highquality cheap beef. In conditions of the Eastern region of Ukraine, when raising the beef of the Aberdeen-Angus breed, resource-saving technology of meat cattle breeding is used. The purpose of these studies was to carry out a comparative study of the various methods of grazing beef cattle with calves in the subsystem on natural pastures and to establish the most effective, low-cost method with subsequent calculations of technological maps with consistent operational processes taking into account labor costs per day and the entire pasturing period. It was found that labor costs significantly influenced the way of grazing livestock, especially when using electric paddle, horse, or foot. Thus, the rates of time spent using the electric heath make up 0,54 minutes/head during its installation and 1,28 minutes/head for general operations, using a horse and grazing on foot $-8,75$ and $11,5 \mathrm{~min} /$ head, respectively. The greatest percentage of man-hours expenses is attributable to general operations: when grazing on foot is $85.3 \%$, while grazing with a horse $-81.4 \%$, and with the use of electric paddle $-45.3 \%$, including the installation of electrical appliances $10 \%$. That is, the advantage of economical use of human labor was on the side of the last method of grazing cattle. Total labor costs in other organicallytechnological operations of the pasturing period, such as loading, transportation, distribution of feed for the feeding of calves and cows, as well as the supply of water, were 1080 human-hours/per period. In order to ensure the fulfillment of all the necessary technological processes and operations in keeping the Aberdeen-Angus cows with calves on the subspecies (220 heads) during the grazing period, natural grazing in the conditions of the ForestSteppe of Ukraine requires the following number of workers: when grazing on foot -9 people, while grazing with a horse -7.5 people, using electric paddle -4 people. Consequently, the expediency of wider use of electric paddles in grazing livestock has been established due to the saving of human labor, fewer workers and more efficient use of pastures.

Key words: meat cattle breeding, pastures, technology, methods of grazing, technological maps, cows of the Aberdeen-Angus breed. 